\title{
MODEL PENDIDIKAN INKLUSIF UNTUK SISWA TUNAGRAHITA DI SEKOLAH DASAR
}

\author{
Asep Supena \\ Fakultas Ilmu Pendidikan, Universitas Negeri Jakarta \\ Email: supena2007@yahoo.com
}

\begin{abstract}
The research aims to produce a model's implementation of inclusive education for students who are syndromic Mental Retardation in elementary school. Research conducted by the method of research and development $(R \& D)$. The research has produced two major findings: (1) a description of the facts and issues of implementation for inclusive education for students who are Syndromic Mental Retardation in elementary school today.; (2) konsep pelaksanaan model pendidikan inklusif bagi siswa tunagrahita di sekolah dasar. The resulted models include 5 main products (1) general guidelines for the implementation of inclusive education, (2) model of curriculum and learning, (3) model lesson plans, (4) evaluation model, (5) syllabus' lessons in elementary school that have been modified for students who are Syndromic Mental Retardation.
\end{abstract}

Keywords: Mental Retardation, inclusive education

\begin{abstract}
Abstrak
Penelitian ini bertujuan untuk menghasilkan implementasi model tentang pendidikan inklusif bagi siswa yang Tunagrahita di sekolah dasar (SD). Penelitian dilakukan dengan metode penelitian dan pengembangan (R \& D). Penelitian ini menghasilkan dua temuan utama, yaitnu (1) deskripsi fakta dan isuisu implementasi pendidikan inklusif bagi siswa tunagrahita di sekolah dasar saat ini; (2) konsep pelaksanaan model pendidikan inklusif bagi siswa yang Tunagrahita di sekolah dasar. Model hasil meliputi 5 produk utama: (a) panduan umum untuk pelaksanaan pendidikan inklusif, (b) model kurikulum dan pembelajaran, rencana Model (c) pelajaran, (d) model evaluasi, pelajaran (e) silabus 'di sekolah dasar yang telah dimodifikasi bagi siswa yang Tunagrahita.
\end{abstract}

Kata kunci: Tunagrahita, pendidikan inklusif

\section{PENDAHULUAN}

Undang-undang Nomor 20 Tahun 2003 tentang Sistem Pendidikan Nasional menyatakan bahwa "Setiap warga negara mempunyai hak yang sama untuk memperoleh pendidikan yang bermutu". Bunyi ayat ini sejalan dengan deklarasi Salamanca (salamanca declaration) pada tahun 1994 tentang pendidikan untuk semua (education for All). Dua gagasan tersebut memberi konsekuensi bahwa semua anak tanpa kecuali mempunyai hak yang sama untuk memperoleh pendidikan, termasuk anak-anak berkebutuhan khusus.

Anak berkebutuhan khusus atau sering juga dikenal dengan sebutan anak luar biasa adalah mereka yang mengalami penyimpang-an atau perbedaan secara signifikan dari keadaan orang pada umumnya (rata-rata), sehingga mereka membutuhkan pelayanan pendidikan secara khusus, supaya dapat mengembangkan potensinya secara optimal (Cullata, et.al., 2003) Di antara mereka, ada yang mengalani penyimpangan pada aspek fisik-motorik, intelektual, sosial dan atau emosi.

Tunagrahita merupakan salah satu jenis dari kelompok anak berkebutuhan khusus. Mereka mengalami hambatan atau keterbelakangan pada fungsi intelektual secara signifikan, sehingga membutuhkan layanan pendidikan yang khusus (Friend, Marilyn, 2005; Abdurrahman dan Sudjadi, 1994; Hardman, et.al., 1990). Secara 
operasional, ada dua kriteria utama yang sering dipakai oleh para ahli untuk menetapkan seseorang tergolong tunagrahita yaitu (1) kemampuan intelektual di bawah rata-rata secara signifikan, yakni IQ di bawah 70 pada skala Wechsler, dan (2) rendahnya perilaku penyesuaian, baik terhadap tuntutan dirinya maupun lingkungan sosial, dan (3) fenomena-nya terjadi pada periode perkembangan yaitu usia di bawah 16 atau 18 tahun

Tunagrahita adalah mereka yang mengalami hambatan atau keterbelakangan fungsi kecerdasan atau intelektual secara signifikan, sehingga membutuhkan suatu layanan pendidikan yang khusus untuk bisa mengembangkan potensi yang ada dalam dirinya. Secara operasional, ada tiga kriteria utama yang sering dipakai oleh para ahli untuk menetapkan seseorang tergolong ke dalam kelompok anak tunagrahita, yaitu (1) kemampuan intelektual di bawah rata-rata, secara signifikan, (2) rendahnya perilaku penyesuaian diri, (3) terjadi pada usia perkembangan (Turnbull, 2004; Friend, 2005; Eggen \& Kauchak, 2004; woolfolk, 2004). Kriteria pertama, tentang kemampuan intelektual di bawah rata-rata umumnya di identifikasikan oleh adanya skor IQ yang menyimpang 2 simpangan baku di bawah rata-rata, yaitu sekitar angka 70 atau 68.

Dengan demikian, seseorang dikatakan terbelakang mental apabila memiliki skor IQ dibawah 70 atau 68 . Kriteria kedua, tentang hambatan prilaku adaptif biasanya menunjuk kepada rendahnya kemandirian dan atau tanggung jawab sosial seorang anak di-banding keadaan usianya dan atau budaya kelompoknya. Misalnya hambatan dalam melaksanakan tugas-tugas akademik dasar seperti membaca, menulis, aritmatik, konsep-konsep dasar bidang studi, keterbatasan dalam melakukan keterampilan untuk memenuhi kebutuhan dirinya, juga ketidakmampuan dalam menjalankan tugas atau peran-peran sosial yang dituntut oleh kelompok atau lingkungan sosialnya. Kriteria ketiga, mengatakan bahwa gejala- gejala eter-belajangan mental seperti yang disebutkan di atas harus terjadi dan teramati ketika anak berada dalam masa perkembangan yaitu usia 18 tahun kebawah.

Dalam perspektif pendidikan, keterbelakangan mental sering dikatagorikan ke dalam empat kelompok (Friend, 2005) yaitu keterbelakangan (1) ringan, (2) sedang, (3) berat dan (4) sangat berat. Tunagrahita Ringan adalah mereka yang memiliki IQ berkisar antara 55 sampai dengan 69. Mereka umum-nya lancar berbicara tetapi perbendaharaan katanya terbatas. Mereka mengalami kesukaran berpikir abstrak, tetapi masih dimungkinkan untuk mengikuti pelajaran akademik walaupun dalam tingkatan yang rendah (sederhana). Sebagian dari mereka dapat mencapai kecerdasan setingkat anak usia 12 tahun, ketika mereka mencapai usia 16 tahun. Secara umum, kecerdasan mereka paling tinggi dapat mencapai kemampuan setingkat anak usia 12 tahun.

Tunagrahita Sedang. Mereka memiliki IQ berkisar 4O-54. Secara umum, mereka hampir tidak bisa mempelajari materi-materi akademik (membaca, menulis dan berhitung). Mereka umumnya belajar secara membeo, yaitu mempelajari dan menguasi sesuatu tanpa akan. Perkembangan bahasanya lebih terbatas dibanding anak tunagrahita ringan. Dapat membedakan bahaya dan tidak bahaya, tetapi mereka hampir selalu bergantung pada petunjuk dan perlindungan orang lain. Mereka masih dapat dilatih kemampuan untuk memelihara dirinya sendiri, dan beberapa pekerjaan yang memiliki nilai ekonomik. Kecerdasan mereka maksimum berkembang serta anak usia 7 tahun.

Tunagrahita berat. Mereka memiliki IQ berkisar 25-39. Hampir seluruh waktu dan aktivitas bergantung kepada pertolongan orang lain. Mereka tidak dapat memelihara dirinya sendiri, seperti makan, berpakaian, mandi dan lain-lainnya. Pada umunya juga tidak dapat membedakan baya dan tidak bahaya. Mereka juga tidak diharapkan dapat berpatisipasi dalam lingkungan sekitarnya. 
Tunagrahita Sangat Berat. Mereka memiliki IQ kurang dari 25. Kondisi mereka umumnya hampir sama seperti terbelakang mental berat. Dalam literatur, memang mereka yang terbelakang mental berat dan sangat berat sering diilustrasikan secara bersama. Perkembangan maksimum kecerdasan mereka setara dengan anak normal usia 3 atau 4 tahun.

Secara umum ada dua pendekatan atau model dalam penyelengaraan pendidikan bagi anak tunagrahita. Pertama model terpisah (segregasi) dan kedua model terintegrasi (mainstreaming). Model segregatif adalah suatu model penyelenggaraan pendidikan, di mana anakanak tunagrahita memperoleh layanan pendidikan di lembaga tersendiri (khusus) yang terpisah dan anak-anak lainnya. Model ini sering disebut dengan istilah Sekolah Luar Biasa. Model terintegrasi (mainstreaming) adalah suatu model penyelenggaraan pendidikan dimana anakanak tunagrahita memperoleh layanan pendidikan secara terintegrasi (bersamasama) dengan siswa lainnya di sekolah umum (sekolah regular). Pendidikan inklusif merupakan salah satu perwujudan pendekatan yang mainstreaming.

Pada dasamya sulit untuk menemukan lembaga pendidikan yang benar-benar segregasi dan yang benar-benar main-streaming. Oleh karena itu, secara lebih rinci penyelenggaraan pendidikan bagi siswa tunagrahita dapat dikelompokkan ke dalam beberapa bentuk sebagai berikut (Gallegher, 1986, Friend, 2005): pertama, general education (full Inclusion). Pada model ini siswa tunagrahita memperoleh layanan pendidikan dan pembelajaran di kelas-kelas reguler secara bersama-sama dengan anak-anak yang lain. Siswa-siswa tunagrahita mendapatkan layanan pendidikan yang sesuai dengan kemampuan dan kebutuhannya. Kurikulum, materi, proses serta evaluasi dirancang dan dijalankan sesuai dengan kondsi anak.

Kedua, resource class. Dalam model mi siswa tunagrahita belajar pada sekolah reguler terdekat dimana anak tinggal. Kurang lebih $50 \%$ waktu belajar diberikan (dilakukan) di kelas khusus secara terpisah dari anak-anak lainnya. Lima puluh persen waktu lainnya digunakan untuk belajar secara bergabung atau bersama dengan siswa lainnya baik di dalam maupun di luar kelas.

Ketiga, separate class (Special Class). Siswa terdaftar dalam suatu sekolah umum (regular), tetapi sebagian besar waktu belajar digunakan di kelas khusus yang sengaja disediakan untuk mereka. Program yang disajikan biasanya berkenaan dengan pengembangan materi atau keterampilanketerampilan khusus yang dibutuhkan. Program mi memungkinkan anak tunagrahita untuk sewaktu-waktu ikut serta ke dalam kelas reguler pada bidang-bidang tertentu sesuai dengan kebutuhan dan minat.

Keempat, separate school (Special school). Program mi berbentuk lembaga atau sekolah yang secara khusus diperuntukkan bagi anak tunagrahita. ini merupakan bentuk sekolah atau lingkungan pendidikan yang benar-benar terpisah dari sekolah umum (reguler). Program ini dapat dilaksanakan dengan sistem harian (day school) dimana anak-anak tetap tinggal di rumah orang tuanya dan pergi ke sekolah setiap hari, atau sistem asrama dimana anak tinggal di asrama yang merupakan bagian terpadu dan sekolah.

Kelima, home or hospital. Ini adalah bentuk alternatif pendidikan untuk anak tunagrahita yang menjalani perawatan kesehatan di rumah atau di rumah sakit. Siswa tunagrahita yang mengalami problem kesehatan yang kronik biasanya harus dirawat dalam kurun waktu yang relatif lama, baik di rumah maupun di rumah sakit. Untuk kondisi seperti ini, maka pembelajaran biasanya dilangsungkan di tempat dimana anak harus dirawat.

\section{A. Pendidikan \\ Inklusif \\ untuk Tunagrahita \\ Ditinjau dari makna kata, inklusi (inclusion) berarti termasuk di dalamnya atau merupakan bagian dari keseluruhan. Inklusif (dari kata inclusive) merupakan kata}


sifat dari inklusi, yang berarti bersifat terbuka, artinya semua orang dapat bergabung untuk menjadi bagian dari keseluruhan. Pendidikan inklusif (inclusive education) secara umum dimaknai sebagai suatu filosofi dan system penyelenggaraan pendidikan dimana semua anak dengan berbagai kondisi dapat mengikuti pendidikan dalam satu lingkungan pendidikan secara bersama. Sekolah yang menerapkan sistem inklusif memberi kesempatan atau membuka diri kepada semua anak untuk mengikuti pendidikan, tanpa membedakan latar belakang agama, social, ekonomi, budaya, suku bangsa dan juga kemampuan.

Dalam konteks pendidikan anak tunagrahita, maka pendidikan inklusif adalah suatu filosofi atau system penyelenggaraan pendidikan, dimana anak-anak tunagrahita mengikuti kegiatan pendidikan dan atau pembelajaran di sekolah-sekolah regular (umum) secara bersama dengan anak-anak lainnya. Anak tunagrahita mendaftarkan diri ke sekolah regular yang dekat dengan tempat tinggalnya. Mereka belajar di kelas-kelas regular secara bersama dengan anak-anak lain-nya, tetapi mereka memperoleh layanan pendidikan yang disesuaikan dengan kemampuan dan kebutuhannya. Ada tiga karakteristik utama dari pelaksanaan pendidik-an inklusif (Eggen \& Kauchak, 2004): (1) anak berkebutuhan khusus mengikuti pendidikan di sekolah reguler (umum), (2) anak berkebutuh-an khusus ditempatkan pada kelas yang sesuai dengan umurnya, dan (3) ketika pembelajaran di kelas, anak berkebutuhan khusus memperoleh layanan pendidikan khusus yang sesuai dengan kemampuan dan kebutuhannya.

Sejalan dengan Eggen \& Kauchak, Turnbull at.all. (2004) menyebutkan ada empat aspek yang menjadi karakteristik dari pendidikan inklusif yaitu (1) anak mengikuti pendidikan di sekolah yang dekat dengan tempat tinggalnya, sebagaimana anak-anak umumnya juga melakukan hal tersebut, (2) jumlah anak berkebutuhan khusus yang ada di kelas reguler bersifat proporsional, sebagai-mana porsi anak berkebutuhan khusus dalam populasi yang sesungguhnya di masyarakat, (3) pelaksanaan pembelajaran di kelas menggabungkan strategi pembelajaran umum dan layanan pendidikan yang khusus, (4) anak berkebutuhan khusus di tempatkan pada kelas yang sesuai dengan usianya.

Tunagrahita membutuhkan layanan pendidikan yang khusus supaya dapat mengembangkan potensinya secara optimal. Kurikulum dan proses pembelajaran perlu dirancang khusus supaya cocok dengan kebutuhan mereka, sehingga pada gilirannya mampu memberdayakan mereka untuk menjadi manusia yang mandiri. Penyelenggaraan pendidikan khusus bagi anak tunagrahita telah menjadi komitmen dari pemerintah Indonesia. Hal ini tampak dari bunyi pasal 5 ayat 2 UU No. 20/2003 yang menyatakan bahwa warga negara yang mempunyai kelainan fisik, emosional, mental, intelektual, dan/atau sosial berhak memperoleh pendidikan khusus.

Fakta di lapangan menunjukkan bahwa masih sangat sedikit anak-anak tunagrahita dan anak berkebutuhan khusus yang telah mendapat kesempatan pendidikan. Data yang bersumber dari BPS menyebutkan bahwa proyeksi jumlah anak berkebutuhan khusus di Indonesia tahun 2008 adalah 1.504 .000 orang, dan 322 ribu di antaranya adalah anak berkebutuhan khusus usia sekolah (5-18 thn). Selajutnya, data direktorat Pembinaan Sekolah Luar Biasa (PSLB) menunjukkan bahwa saat ini jumlah anak berkebutuhan khusus yang telah mendapat pendidikan di sekolah luar biasa adalah 66.610 anak. Dengan demikian, baru sekitar 20\% anak-anak berkebutuhan khusus usia sekolah (termasuk di dalamnya tunagrahita) yang telah mendapat kesempatan mengikuti pendidikan.

Kecilnya akses pendidikan untuk anak tunagrahita dan anak berkebutuhan khusus pada umumnya, disebabkan karena masih sedikitnya jumlah sekolah luar biasa (SLB) di Indonesia. Data Depdiknas menyebutkan bahwa saat ini tercatat hanya 
ada 1569 SLB di seluruh Indonesia dari mulai jenjang TK sampai dengan sekolah menengah. Dari jumlah tersebut hanya 302 sekolah yang dikelola oleh pemerintah (sekolah negeri). Ada dua persoalan mendasar yang menyebabkan lambannya pengembangan sekolah luar biasa, yaitu (1) pendirian SLB perlu biaya investasi yang mahal, (2) di sisi lain keberadaan anak berkebutuhan khusus tidak terkonsentrasi di suatu wilayah dalam jumlah yang banyak, tetapi tersebar di berbagai lokasi dan pelosok. Kondisi ini menyebabkan semakin tidak ekonomisnya pendirian SLB.

Untuk mengatasi persoalan tersebut, saat ini ada satu pemikiran yang dianggap merupakan terobosan yang efektif untuk menanggulangi masalah kesempatan pendidikan bagi anak-anak tunagrahita, yakni konsep "pendidikan inklusif". Pendidikan inklusif adalah suatu filosofi dan juga strategi dalam pendidikan, dimana anakanak dengan berbagai kondisi (termasuk anak berkebutuhan khusus) dapat mengikuti pendidikan secara bersama-sama di sekolah reguler (sekolah umum). Pemikiran ini menjanjikan adanya peningkatan kesempatan pendidikan yang signifikan bagi siswa tunagrahita, karena pendidikan inklusif membuka peluang kepada siswa tunagrahita untuk mengikuti pendidikan di sekolah reguler (sekolah umum) mana saja yang dekat dengan tempat tinggalnya.

Pendidikan inklusif telah mulai digulirkan oleh pemerintah. Sejumlah sekolah reguler telah ditetapkan sebagai sekolah inklusif baik negeri maupun swasta. Di DKI Jakarta misalnya, saat ini tercatat ada 59 sekolah yang ditetapkan sebagai sekolah inklusif, yang meliputi sekolah dasar, SMP, SMA dan SMK. Sekolah-sekolah tersebut disamping menjalankan misinya memberi layanan pendidikan kepada siswa "umum", mereka juga menerima dan melayani pendidikan untuk anak-anak berkebutuhan khusus. Di Jawa Barat tercatat ada 189 sekolah yang ditetapkan sebagai sekolah inklusif, dan 140 di antaranya adalah sekolah dasar.
Pendidikan inklusif sudah berjalan, tetapi ada sejumlah permasalahan mendasar yang ditemukan di lapangan. Hasil studi kasus yang dilakukan oleh penulis terhadap pelaksanaan pendidikan inklusif untuk siswa tunagrahita (Supena, 2008), menemukan adanya beberapa permasalahan dalam pelaksanaan pendidikan inklusif di antaranya adalah menyangkut kebijakan yang belum kokoh, persepsi dan komitmen masyarakat yang belum merata, ketersediaan SDM yang belum memadai, serta sistem kurikulum dan pembelajaran yang belum kondusif terhadap pendidikan inklusif. Terkait dengan kurikulum dan pembelajaran, ada tiga permasalahan utama yang dihadapi yaitu (1) bagaimana model kurikulum dan rencana pembelajaran dalam konteks pendidikan inklusif? (2) bagaimana model pelaksanaan proses pembelajaran dalam konteks pendidikan inklusif? dan (3) bagaimana model pelaksanaan evaluasi pembelajaran dalam konteks pendidikan inklusif?

Penelitian ini bertujuan untuk memetakan dan menjawab tiga permasalahan tersebut. Tujuan akhirnya adalah menghasilkan suatu model pelaksanaan pendidikan inklusif yang efektif untuk siswa tunagrahita di sekolah dasar yang merujuk kepada tiga permasalahan tersebut.

\section{METODOLOGI PENELITIAN}

Penelitian dilaksanakan dengan menggunakan metode penelitian untuk pengembangan atau yang sering dikenal sebagai research and development (Sugiyono, 2006). Penelitian diawali dengan pengumpulan data tentang situasi dan kondisi pelaksanaan pendidikan inklusi yang ada saat ini (existing condition), sehingga diperoleh gambaran tentang profil pelaksanaan pendidikan inklusi secara detail dan menyeluruh. Selanjutnya dirancang suatu model hipotetik tentang penyelenggaraan pendidikan inklusi untuk anak tunagrahita yang dianggap ideal. Model selanjutnya akan mengalami pengujian dan revisi pada beberapa tahap. Setelah model 
terbukti efektif maka model akan didesiminasi dan diimplementasi-kan dalam praktik pendidikan.

Penelitian dilaksanakan dalam tiga tahap (3 tahun). Artikel ini merupakan laporan penelitian tahap pertama (tahun pertama). Pada tahap ini, penelitian difokuskan pada dua target utama yaitu (1) mengkaji fakta dan permasalahan penyelenggaraan pendidikan inklusif untuk siswa tunagrahita di sekolah dasar saat ini, (2) mengembangkan konsep model pelaksanaan pendidikan inklusif untuk siswa tunagrahita di Sekolah Dasar. Untuk mencapai dua sasaran tersebut, ada dua kegiatan utama yang dilaksanakan yaitu (1) pengumpulan data, dan (2) pengembangan model. Pengumpulan data dilakukan dengan menggunakan beberapa cara dan alat secara terintegrasi, yaitu wawancara, kuesioner, pengamatan, analisis dokumen, seminar, dan diskusi kelompok terbatas (focus group discussion). Sedangkan kegiatan pengembang-an model dilakukan melalui kajian teori, kegiatan seminar, workshop, dan focus group discussion.

Sebanyak 42 Sekolah Dasar inklusif dan 3 Sekolah Luar Biasa (SLB) telah dilibat-kan dalam penelitian ini. Sekolahsekolah tersebut berada di empat wilayah utama yaitu DKI Jakarta, Kota Bogor, Kabupaten Bogor, Pandeglang dan Kabupaten Bandung. Selain itu ada 40 sekolah dasar non-inklusif yang tersebar di lima propinsi lain yang dijadikan lokasi tambahan untuk mengumpulkan data tentang sikap mereka terhadap pelaksanaan pendidikan inklusif yaitu Bangka Belitung, Jambi, Aceh, Kalimantan Selatan dan Gorontalo. Sejumlah propinsi lainnya juga telah dilibatkan sebagai lokasi tambahan untuk memperkaya kajian tentang permasalahan pelaksanaan pendidikan inklusif serta pemikiran dalam pengembangan program pendidikan inklusif yaitu propinsi Aceh, Jawa Te-ngah, Sulawesi Selatan, dan Maluku Utara. Perolehan informasi pada wilayah-wilayah tersebut dilakukan melalui kegiatan seminar dan workshop yang diselenggarakan atas kerja sama Helen Keller Internasional (HKI), MCPM-AIBEP dan direktorat PSLB Depdiknas. Sumber data dalam penelitian ini meliputi guru, kepala sekolah, pengawas dan pejabatan dinas pendidikan terkait.

\section{HASIL DAN PEMBAHASAN}

Ada dua katagori hasil yang dicapai dalam penelitian tahap pertama (tahun pertama) yaitu (1) realita dan permasalahan penyelenggaraan pendidikan inklusif untuk siswa tunagrahita di SD, (2) model penyelenggaraan pendidikan inklusif untuk siswa tunagrahita di SD.

\section{A. Fakta dan Permasalahan}

Dalam penelitian tahun pertama ini peneliti menemukan sejumlah fakta dan permasalahan sehubungan dengan pelaksana-an pendidikan inklusif di Sekolah Dasar, yaitu sebagai berikut: pertama, masih rendahnya pemahaman guru-guru tentang anak berke-butuhan khusus (ABK) dan bagaimana pelaksanaan layananan pendidikan untuk mereka dalam konteks inklusif. Hal ini dapat dipa-hami karena mereka adalah guru regular (umum) yang tidak memiliki latar dan kualifikasi pendidikan khusus. Kondisi ini memberi konsekuensi atau implikasi yang luas bagi keseluruhan aktivitas pendidikan untuk siswa berkebutuhan khusus. Artinya pelaksanaan layanan pendidikan untuk anak berkebutuhan khusus pada hampir semuan komponen menjadi kurang optimal karena terbatasanya pemahaman dan kompetensi guru tentang $\mathrm{ABK}$.

Data penelitian menunjukkan bahwa proporsi terbesar dari guru-guru yang diteliti melaporkan bahwa mereka merasa kurang jelas tentang status kelainan yang ada pada anaknya di kelas. Artinya mereka masih ragu dan samar apakah anaknya tergolong berkebutuhan khusus. Jika pun mereka menduga bahwa siswanya adalah ABK, mereka juga belum sepenuhnya paham apa jenis kelainan atau hambatan yang mereka alami. Ini adalah persoalan mendasar yang 
dihadapi guru-guru regular yang melaksanakan pendidikan inklusif.

Kedua, belum ada petunjuk (pedoman) praktis yang dapat dijadikan panduan oleh para guru dalam melaksanakan proses belajar mengajar bagi anak tunagrahita yang ada di kelas inklusif. Kondisi ini semakin memper-buruk persoalan yang dihadapi oleh guru-guru inklusi sebagaimana disebutkan pada butir satu. Mereka tidak memiliki pemahaman dan kompetensi yang memadai tentang pendidikan anak berkebutuhan khusus. Kemudian mereka juga tidak mendapati buku pedoman atau petunjuk yang dapat dibaca sebagai rambu-rambu dalam memberikan layanan pendidikan kepada mereka.

Sejauh ini, direktorat pembinaan sekolah luar biasa (PSLB) sebenarnya telah membuat dan mengeluarkan pedoman penyelenggaraan pendidikan inklusif yang terbagi ke dalam beberapa buku. Akan tetapi ada sejumlah kendala terkait dengan buku pedoman ini, yaitu (1) buku ini bersifat umum untuk seluruh jenis anak berkebutuhan khusus, padahal karakteristik hambatan dan kebutuhan siswa ABK sangat berbeda antara satu jenis kelainan dengan jenis lainnya. Sehingga kurang memberikan penjelasan yang spesisifk dan operasional. (2) buku ini telah dibuat tetapi belum terdistribusikan dan tersosialisasikan secara optimal kepada seluruh sekolah inklusif yang berkepentingan.

Banyak sekolah-sekolah yang inklusif yang belum memiliki. Sekolah yang sudah memiliki pun belum bisa memahami isi pedoman tersebut sepenuhnya. Tidak tersedianya buku pedoman yang spesifik dan operasional berdampak terhadap persoalanpersoalan teknis pelaksanaan pendidikan inklusif di antaranya adalah tidak tersusunnya silabus dan rencana pembelajaran yang sesuai dengan siswa tunagrahita, terjadinya pelaksanaan pembelajaran yang yang tidak optimal (spekulatif), terjadinya pelaksanaan evaluasi yang tidak tepat.
Ketiga, belum tersedianya perangkat pendukung pelaksanaan pembelajaran inklusif siswa tunagrahita secara memadai. Di antaranya adalah (1) belum tersedia perangkat dasar kurikulum yang dirancang khusus untuk siswa tunagrahita. Hal yang paling mendasar terkait dengan aspek ini adalah belum tersedianya silabus khusus untuk pembelajaran siswa tunagrahita, yang akan berfungsi sebagai kerangka dasar dalam mengembangkan rencana dan proses pembelajaran. (2) belum tersedia sarana, peralatan dan media pembelajaran yang memadai untuk men-dukung pelaksanaan pembelajaran bagi siswa tunagrahita di kelas inklusif (3) belum tersedia sumber atau bahan belajar khusus untuk siswa tunagrahita, baik berupa buku maupun bahan yang dkembangkan sendiri oleh guru. (3) belum tersedia sistem yang ajeg tentang pelaksanaan evaluasi bagi siswa tunagrahita yang berada di sekolah inklusif. Ajeg artinya sistem yang telah disepakti, menetap dan memiliki landasan hukum yang jelas, sehingga semua pihak melaksanakan dan mempersepsi secara sama.

Keempat, belum tersedianya landasan hukum yang pasti dan jelas yang menjamin terhadap pelaksanaan pendidikan inklusif yang bermutu. Sejauh ini telah ada UU no 20 tahun 2003 tentang system pendidikan nasi-onal, juga rancangan peraturan pemerintah (RPP) tentang penyelenggaraan pendidikan. Akan tetapi kedua landasan tersebut belum memberikan landasan secara kuat dan operasional terhadap jaminan pelaksanaan pendidikan inklusif bagi siswa berkebutuhan khusus secara bermutu. Sejumlah daerah telah memiliki pergub yang khusus mengatur tentang penyelenggaraan pendidikan inklusif, tetapi kondisi itu hanya terjadi di beberapa daerah, salah satunya adalah DKI Jakarta. Pengamatan di lapangan menunjukkan bahwa saat ini telah dikembangkan/dirancang peraturan menteri tentang penyelenggaraan pendidikan inklusif. Selama penelitian berjalan, terlihat bahwa rancangan permen ini cukup 
memberikan landasan bagi pelaksanaan pendidikan inklusif secara baik dan bermutu, akan tetapi belum bisa dipastikan kapan permen ini benar-benar akan diberlakukan. Permen akhirnya telah disyahkan beberapa saat menjelang pergantian menteri. Dengan demikian sekarang telah ada landasan hukum yang lebih operasional tentang pelaksanaan pendidikan inklusif. Pertanyaannya adalah bagai-mana implementasi permen tersebut di lapangan.

Kelima, Persepsi dan dukungan berbagai pihak yang belum sama. Sejumlah kalangan telah memiliki pemahaman dan sikap yang positif terhadap pelaksanaan pendidikan inklusif khususnya untuk siswa tunagrahita misalnya para guru, orang tua dan kepala sekolah yang ada di sekolah inklusif. Akan tetapi sejumlah pihak lainnya belum sepenuh-nya memiliki pemahaman yang tepat/positif. Pihak-pihak yang masih perlu diberikan sosialisasi sehingga memiliki pemahaman yang sama di antaranya adalah guru dan kepala sekolah yang belum menyelenggara-kan pendidikan inklusif, pengawas sekolah umum, pejabat dinas pendidikan dan deper-temen pendidikan yang terkait, serta orang tua dan masyarakat secara luas. Informasi dari lapangan menunjukkan bahwa para guru di sekolah inkusif umumnya telah memiliki memahami dan sikap yang positif tehadap pendidikan inklusif, yang mereka risaukan adalah pemahaman dan sikap dari pengawas sekolah serta pejabat dinas pendidikan yang terkait. Para guru terkadang mengalami kendala teknis dalam pelaksanaan pembelajar-an inklusif karena adanya perbedaan pemahaman dan sikap dengan pengawas dan pejabat dinas terkait. Faktor ini sangat penting dicermati dan dicarikan solusinya, karena akan menjadi landasan bagi terselenggaranya pendidikan inklusif.

Keenam, permasalahan teknis yang teramati dan disampaikan oleh sejumlah guru di sekolah inklusif adalah keberadaan ABK yang jumlahnya terlalu banyak dalam satu kelas atau sekolah. Data temuan yang telah disajikan terdahulu menunjukkan bahwa banyak sekolah yang memiliki ABK lebih dari 40 orang, bahkan ada sekolah yang tercatat memiliki lebih dari 70 siswa ABK. Dengan kondisi ini maka jumlah $A B K$ di setiap kelas bisa mencapai 5 sampai 7 orang. Kondisi ini tentu saja tidak cukup kondusif bagi terselenggaranya layanan pembelajaran yang optimal karena bisa dipastikan guru akan mengalami kekurangan waktu, tenaga dan kemampuan untuk melayani mereka yang kondisinya bermasalah dan beragam. Kondisi ini juga diperburuk dengan permasalahan lain yaitu jumlah keseluruhan siswa dalam satu kelas yang terlalu banyak.

Ketujuh, kendala teknis lain yang teramati dan tertangkap adalah tentang tugas dan beban para guru yang cukup lumayan banyak khususnya terkait dengan tuntutan kurikulum yang padat dan cukup ideal. Guru-guru dikejar target untuk memenuhi standar-standar penguasaan dan standar kelulusan yang telah ditetapkan. Situasi ini kemudian dipertajam dengan adanya tuntutan ujian nasional bagi siswa sekolah dasar yang semakin membuat guru SD sibuk dan tertuju pada pencapaian prestasi yang tinggi. Ketika guru dituntut untuk mencapai standar-standar prestasi yang tinggi, pada saat bersamaan mereka juga dituntut untuk memberikan pelayanan yang khusus bagi siswa-siswa berkebutuhan khusus. Ini adalah masalah, kesulitan sekaligus tantangan yang harus dijawab bukan saja oleh guru tetapi juga semua pihak yang terkait dan peduli dengan pendidikan.

Kedelapan, belum tersedianya tenaga dan sumber pendukung utama untuk terselenggaranya pendidikan inklusif yang mema-dai, yaitu guru pendidikan khusus (GPK) dan pusat sumber (resource center). GPK adalah guru yang memiliki kualifikasi pendidikan dan keahlian di bidang pendidikan luar biasa. Mereka berfungsi untuk mendampingi sekolah inklusif dalam menjalankan misinya memberi layanan pendidikan kepada anak-anak berkebutuhan khusus. Data di lapangan menunjukkan bahwa saat ini jarang sekolah-sekolah yang memiliki guru pendidikan khusus (GPK), 
padahal mereka deperlukan kehadirannya untuk menunjang pelaksanaan pembelajaran yang bermutu. Pusat sumber (resource center) adalah lembaga yang memiliki SDM, kemampuan dan peralatan untuk memberi layanan pendidikan kepada anak berkebutuhan khusus, yang diberi tugas untuk mendampingi dan membantu sekolahsekolah inklusif dalam menjalankan tugasnya memberi layanan pendidikan kepada ABK. Saat ini keberadaan pusat sumber juga masih terbatas, sehingga belum bisa menyentuh dan mendampingi semua sekolah inklusif.

Kesembilan, fakta lain yang masih sering menjadi problem atau kendala mendasar dalam pelaksanaan pendidikan inklusif adalah pelaksanaan evaluasi bagi siswa tunag-rahita yang ada di sekolah inklusif. Sejauh ini masih terjadi keragaman, ketidakpastian atau kesimpangsiuran dalam pelaksanaan evaluasi bagi siswa tunagrahita, baik tentang jenis soal evaluasi, kebijakan tentang ujian nasional, bentuk raport, isu kenaikan kelas, kelulusan dan bentuk ijazah sebagai bukti kelulusan. Sebagian sekolah menggunakan soal ujian sumatif yang sama antara siswa tunagrahita dengan siswa lainnya, sebagiannya lagi membedakan. Sebagian sekolah mengha-ruskan siswa tunagrahita untuk mengikuti ujian nasional sebagian lain tidak. Sebagian sekolah menggunakan soal USBN umum untuk diberlakukan kepada siswa tunagrahita sebagian lainnya menggunakan soal dari $\mathrm{SLB} / \mathrm{C}$.

Sebagian sekolah inklusif mengeluar-kan ijazah sendiri untuk siswa tunagrahita sebagiannya lagi menggunakan ijazah dari SLB karena mereka memakai soal ujian SLB ketika mengikuti ujian nasional. Intinya adalah belum ada auatu system atau aturan yang ajeg tentang bagaimana seharusnya siswa tuna grahita yang ada di sekolah regular harus menjalani evaluasi dengan berbagai aspeknya.

\section{B. Model Pendidikan Inklusif}

Dalam penelitian tahun pertama ini peneliti telah menghasilkan suatu model pelaksanaan pendidikan inklusif untuk siswa tunagrahita yang ada di satuan pendidikan sekolah dasar (SD) reguler. Model pendidikan yang dihasilkan meliputi lima produk utama yaitu (1) pedoman umum pelaksanaan pendidikan inklusif untuk siswa tunagrahita di SD (2) model kurikulum dan pembelajaran (3) model perencanaan pembelajaran (4) model evaluasi dan (5) silabus pembelajaran untuk siswa tunagrahita di SD.

Gambaran umum dari masingmasing produk dapat dilihat pada uraian berikut:

Pertama, pengembangan petunjuk atau pedoman umum pelaksanaan pendidikan inklusif untuk siswa tunagrahita di sekolah dasar. Naskah ini merupakan panduan umum tentang bagaimana menyelenggarakan pen-didikan inklusif untuk siswa tunagrahita di Sekolah Dasar. Di dalamnya memuat informasi tentang latar belakang penyeleng-garaan pendidikan inklusif, pengertian pendidikan inklusif, landasan hukum dan beberapa petunjuk tentang apa yang harus dilakukan untuk dapat menyelenggarakan pendidikan inklusif.

Kedua, pengembangan model kurikulum dalam pembelajaran inklusif untuk siswa tunagrahita di sekolah dasar. Naskah ini memuat petunjuk tentang strategi dalam memodifikasi kurikulum untuk pembelajaran siswa tunagrahita di Sekolah Dasar. Ada empat aspek utama kurikulum yang disoroti yaitu modifikasi tujuan, modifikasi materi, modifikasi proses dan modifikasi evaluasi. Naskah juga menyajikan empat kemungkinan model utama yang dapat dipertimbangkan dalam mengembangkan kurikum pembelajar-an inklusif yaitu duplikasi, modifikasi, substitusi dan omisi.

Ketiga, pengembangan model rencana pembelajaran untuk siswa tunagrahita di sekolah dasar inklusif. Naskah ini memuat penjelasan tentang bagaimana 
cara mengembangkan rencana pembelajaran untuk siswa tunagrahita yang belajar di sekolah inklusif. Ada dua model utama yang ditawarkan yaitu tencana pembelajaran yang teraintegrasi dan rencana pembelajaran individual (individualized education program). Rencana pembelajaran yang ditawarkan difokuskan kepada cara atau strategi dalam melakukan modifikasi terhadap rencana pembelajaran umum yang saat ini digunakan oleh guru-guru di Sekolah Dasar. Naskah ini mengkaji dua bentuk rencana pembelajaran yang biasa dibuat oleh guru yaitu Silabus dan Rencana Pelaksanaan Pembelajaran (RPP).

Keempat, pengembangan model evaluasi untuk siswa tunagrahita di sekolah dasar inklusif. Naskah ini berisi penjelasan tentang cara-cara dalam melaksanakan evaluasi bagi siswa tunagrahita yang ada di Sekolah Dasar inklusif. Di dalamnya mengkupas empat komponen utama yaitu (1) pengembangan instrumen evaluasi, (2) pelaksanaan evaluasi, (3) kriteria keberhasilan dan (4) pelaporan hasil evaluasi.

Kelima, model silabus. Naskah ini merupakan bagian dari pengembangan model kurikulum dan juga meodel rencana pembelajaran. Di dalamnya berisi silabus mata-mata pelajaran utama di sekolah dasar yang telah dimodifikasi untuk siswa tuna grahita yang masuk kagori ringan (C1) dan sedang (C). Ada 8 mata pelajaran yang telah berhasil dikembangkan silabusnya yaitu IPA, Matematika, Bahasa Indonesia, PKn, IPS, Agama Islam, pendidikan jasmani dan kesehatan, Seni Budaya dan Keterampilan.

\section{PENUTUP Simpulan}

Berdasarkan paparan sebelumnya peneliti menyimpulkan bahwa Tunagrahita membutuhkan layanan pendidikan yang khusus supaya dapat mengembangkan potensinya secara optimal. Kurikulum dan proses pembelajaran perlu dirancang khusus supaya cocok dengan kebutuhan mereka.
Pendidikan inklusif adalah suatu filosofi dan juga strategi dalam pendidikan, di mana anak-anak dengan berbagai kondisi (termasuk anak berkebutuhan khusus) dapat mengikuti pendidikan secara bersama-sama di sekolah reguler (sekolah umum).

Pelaksanaan pendidikan inklusif masih menghadapi sejumlah kendala mendasar di antaranya adalah persoalan kebijakan yang belum kokoh, sikap dan komitmen berbagai pihak yang belum merata, sarana dan prasaran yang belum memadai, kendala SDM serta sistem kurikulum, pembelajaran yang belum kondusif, dan belum tersedianya suatu model pelaksanaan pendidikan inklusif yang dapat dijadikan rambu-rambu dalam melaksanakan pendidikan inklusif.

\section{DAFTAR PUSTAKA}
Cullata, T., \& Werts. (2003). Fundamentals of Special Education: Second Edition. New Jersey: Merrill Prentice Hall.

Pusat Statistik Pendidikan, badan Penelitian dan Pengembangan. (2007). Statistik Persekolah PLB 2006/2007. Jakarta: Departemen Pendidikan Nasional

Eggen, P., \& Kauchak, D. (2004). Educational Psychology: Windows on Classrooms Sixth Edition International Edition. New Jersey: Pearson Prentice Hall.

Erez, F., \& Peled. I. (2001). Cognition and Metacognition: Evidence of Higher Thinking in Problem Solving of Adolescents With Mental Retardation. Education and Training in Mental Retardation and Developmental Disabilities, 36, 8393.

Friend, M. (2005). Special Education: Contemporary Perspectives for School Professionals. New York: Pearson Education, Inc. 
Jurnal Parameter Volume 29 No. 2

DOI : doi.org/10.21009/parameter.292.03

P-ISSN : 0216-26IX

Sminth, J. D. (2006). Inklusi, Sekolah Ramah Untuk Seтua. Terjemahan oleh M.Sugiarmin dan MIF Baihaqi. Bandung: penerbit Nuansa.

Sugiyono. (2006). Metode Penelitian Pendidikan: Pendekatan kuantitatif, Kualitatif dan $R \& D$. Bandung: Penerbit Alfabeta.

Supena, A. (2008). Pelaksanaan Pendidikan Inklusif bagi Siswa Tunagrahita di Sekolah Dasar Negeri Batu Tulis
Bogor. Laporan Penelitian tidak diterbitkan. Jakarta: Universitas Negeri Jakarta.

Tumbull, R., Turnbull, A., Shank, M., \& Smith, S.J. (2004). Exceptional Lives: Special Education in Today's School. New Jersey: Pearson Prentice Hall.

Woolfolk, A. (2004). Educational Psychology: Ninth Edition, International Edition. Boston: Pearson education, Inc. 